\title{
Big sciences united in reshuffle of SERC
}

London. A restructuring of the UK Science and Engineering Research Council (SERC) has thrown together nuclear physics and astronomy and given one board the responsibility for most of SERC's big international projects. The change, which will take effect in the autumn of 1993, sets Britain apart from countries such as France, the United States and Germany, where nuclear physics and astronomy are largely managed separately.

Most commentators have greeted the change favourably, saying that the advantages outweigh the possible conflicts of interest that may arise. Although bigscience projects will still have to compete for funds, this will take place within the structure of the new board rather than between boards at the council level. It is hoped that the new forum will permit a more informed discussion of the proposed science, the level of funding being requested and issues peculiar to international science.

A more explicit review of the way in which SERC handles international issues will take place under the most recent corporate plan, but details of this review are not yet public. Between now and the implementation of the new board structure, alterations are also expected to be made to the internal organization of each board. It is these changes that will have the greatest effect on researchers applying for grants.

The main aim of the restructuring, which has been on SERC's agenda for some years, was to reduce the number of interdisciplinary committees that had sprung up at the boundaries between the old order of boards. These were seen by the SERC's management as too bureaucratic and as an indication that the existing board structure did not reflect the state of British research.

Under the new structure, a Physics, Space and Astronomy Board will handle astronomy, astrophysics, Solar System and planetary science, particle physics, nuclear structure physics, atomic physics, plasma physics and Earth observation and geophysics. This arrangement reflects a merging of the old Nuclear Physics Board and the Astronomy and Planetary Science Board, plus some stray physics disciplines from the old Science Board.

A Science and Materials Board will handle materials science and engineering, condensed matter physics, mathematics, chemistry, biology and science-based archaeology. An Engineering and Technology Board has absorbed the old Engineering Commission, covering all the major branches of engineering, and will also handle biotechnology, information technology, computers applied to manufacturing and industrial clean technology.

Although the new structure proposes that materials science and engineering should be handled by the Science and Materials Board, there is apparently still some dispute about how this arrangement will work in practice.

Ian Mundell

\section{Australian universities squeezed}

Sydney. Australian universities have reacted angrily to a government proposal to spend more on research by taking the money from a fund used for their general operating costs.

The Ministry of Finance has proposed adding up to A\$160 million (US\$120 million) to the existing A $\$ 280$-million federal research grants programme, a suggestion that would normally be greeted with applause. But the catch is that the extra money will be diverted from the general federal grants made annually to each university. Australian universities depend heavily on federal funds, which are used to operate libraries and other university services as well as to repair and renovate buildings.

The universities say that they need more money to ease a growing shortage of space on campus. Diverting their discretionary funds into research grants, they argue, will not help. The universities would still receive the same amount of money as before, but it could be spent only on specific research grants to faculty.

The proposal was submitted late last month as part of the government's request for next year's budget. A decision will be made in August.

The issue is far from settled. University officials say that they are still feeling the effects of a similar shift two years ago of 1 per cent of their general operating funds into research. John Clark of Macquarie University in Sydney, speaking for the Australian vice-chancellors (university heads) committee, says that some departments are so crowded that new graduate students lack desks and that limited laboratory facilities and crowded libraries are hampering research. Reducing discretionary funds to universities would make this situation worse, he said.

\section{Hughes Medical Institute reaches further out}

Washington. Later this year, the Howard Hughes Medical Institute will make its second major expansion outside the United States by funding 25 researchers in Britain, Australia and New Zealand.

The five-year awards, along with the continuing grants from last year's forays into Canada and Mexico, will bring the budget of Hughes' new international programmes to nearly $\$ 5$ million a year - slightly less than 10 per cent of its annual grants programme, which is separate from the institute's main research effort and its more than 200 investigators. Although the grants programme is a small amount of the institute's total research spending - about \$220 million in 1990 US tax authorities require Hughes to spend most of its money on scientists who are officially employees of the institute. Because it is difficult to hire foreign scientists as Hughes employees, the international programme is expected to stay a part of the smaller grants component, which began by funding pre-graduate science education and is free of the tax restrictions.

The new programme began to take shape last August, when Hughes officials asked medical school deans in the three countries to nominate researchers. They selected 300 nominees, each of whom was asked to submit proposals. A panel will evaluate the proposals in September, and the winner will be announced by the end of the year.

Hughes officials say their decision to pick three anglophone countries in its first reach across the oceans was based on the fact that Hughes panels find it easier to evaluate research quality in English-speaking countries. Britain also had a boost because of the "feeling that the scientific community owed a great deal to UK advances", says Purnell Choppin, Hughes president. Researchers in the three countries tend to work closely with each other, and the well-publicized funding crisis in British science also "entered into our decision", he says.

Choppin points out that the institute considered several other regional and scientific groupings, at least one of which may be selected in a potential third round of grants in the next year or two. But Hughes has resisted pressure to support research in the former Soviet Union and eastern Europe, in part because of the institute's determined concentration on research quality.

"Everything we do is based on an ability to identify the most promising scientists," says Choppin. Layers of bureaucracy and institutional politics make it difficult to separate the wheat from the chaff in the former Soviet Union, he says.

Christopher Anderson 